\title{
消波機能と魚礁機能を有する 新型被覆ブロックの開発 DEVELOPMENT OF THE NEW TYPE ARMOR BLOCK WITH THE EFFECTS OF WAVE ATTENUATIONS AND ECO-REEF FOR FISH
}

\author{
谷野賢二 1 -梅沢信敏 $2 \cdot$ 上久保勝美 $3 \cdot$ 川原眞 4 - 柳沼利信 5 - 時川和夫 6 \\ Kenji YANO, Nobutoshi UMEZAWA, Katsumi KAMIKUBO, \\ Makoto KAWAHARA, Toshinobu YAGINUMA and Kazuo TOKIKAWA
}

\begin{abstract}
1 正会員 工博 北海道東海大学 工学部 海洋環境学科（T005-8601 北海道札幌市南区南沢 5 条 1 丁目 1-1）
2 正会員 独立法人 北海道開発土木研究所 環境水工部 ( $0061-8602$ 北海道札幌市豊平区平岸 1 条 3 丁目)

3 正会員 独立法人 北海道開発土木研究所 環境水工部 (T061-8602 北海道札幌市豊平区平岸 1 条 3 丁目)

${ }^{4}$ 正会員 東洋建設株式会社 北海道支店 土木部（于001-004 北海道札幌市中央区北 4 条西 6 丁目 1-1）

${ }^{5}$ 東洋建設株式会社 北海道支店（T001-004 北海道札幌市中央区北 4 条西 6丁目 1-1）

${ }^{6}$ 正会員 工博 東洋建設株式会社 北海道支店 （T001-004 北海道札幌市中央区北 4 条西 6 丁目 1-1）
\end{abstract}

Eco-reef concrete blocks have not only a characteristic for the wave force attenuations such as the wave shock-pressure, run-up and scouring the bed mound, but for the construction cost benefit to use an industrial scrape such as dredging mud or sand for the reef, just banking, and have a much contribution to the surrounding environment ecology. The block has been developed, with the mentioned merits, is a box-type and has some open slits on the walls

The paper mentions the hydraulics characteristics of the artificial reef by the eco-reef concrete blocks, for the wave reflections, transmissions, set-up behind the reef, and the stability of the block to compare with the concrete armor unit or the rubble stones. Further, after banking a small mound such as the same rubble mounds behind the artificial reef with the eco-reef blocks, the wave transmission are measured and analyzed the efficiency for the wave transmissions attenuation.

Key Words: artificial reef breakwater, new type armor block, wave attenuations, eco-reef, deepwater

\section{1 .まえがき}

これまで, 海岸・港湾・漁港施設等に用いられる コンクリートブロックは, 消波ブロック, 被覆ブロ ック，魚礁ブロックのように，用途別に単一な機能 を有するものとして製作されてきた。本論文で提案 する立体構造の新型被覆ブロック（以下，エコリー フブロックと呼ぶ）は，本体の被覆機能に加え，消 波機能，魚礁機能，工費縮減効果を併せ持つもので あり，種々の施設に対応が可能であると考える。本 報告では，海岸保全施設として各地に建設されてい る人エリーフ 1)に着目し, 特に大水深域での人エリ 一フの被覆材としてエコリーフブロックを利用する 場合について，検討した結果を示す.

\section{2. 検討内容}

大水深域に人エリーフを設置する場合, 堤体材料 として石材を用いて所要の消波効果を得るためには 水深が浅い場合に比べて大量の捨石が必要となり,

一般に不経済となる。こうした欠点の解決策の一つ として, 捨石の代わりに海水に溶出しない建設廃材 や建設発生土あるいは石炭灰等のリサイクル材を活 用することが考えられる。これら建設廃材等を早期 かつ経済的に海中に投入するためには，図-1のよう な，事前に高い消波効果をもつ小規模な人エリーフ の建設が必要となる. 小規模な人工リーフの被覆材 としてエコリーフブロックを使用することで, 種々 のエコリーフブロックの特性が活かせると考えた. すなわち，エコリーフブロックは立体構造であるこ 


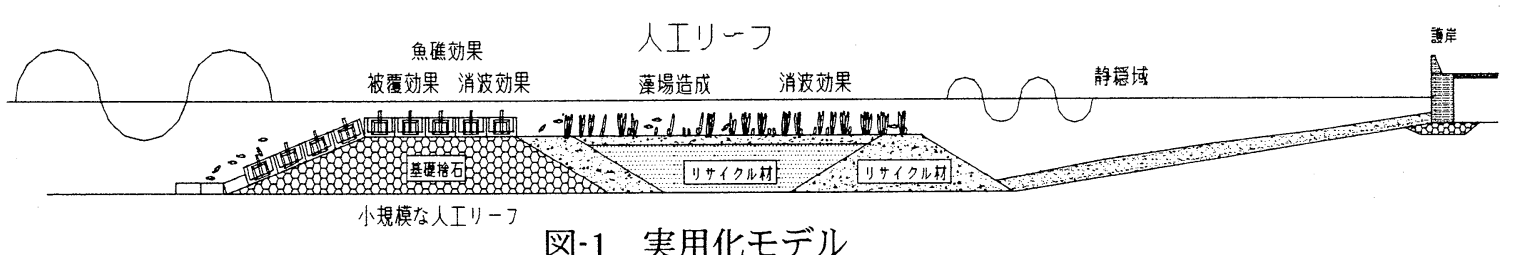

図-1＼cjkstart害用化モデル

とから, 同じ天端高の人エリーフに比べ捨石量を減 らすことができる.また，立体構造は消波機能や魚 礁機能を併せ持つことを可能とする. さらに，エコ リーフブロック背後にリサイクル材で小段を設ける ことによって，小段によるエネルギー散冕効果に加 え, 小段の海藻類の生育場として利用が可能となる.

本検討では，不規則波を用いた水理模型実験によ って，エコリーフブロックを人エリーフの被覆材と して用いた場合の耐波安定性とともに, 人エリーフ の波高伝達率, 反射率および堤体背面の平均水位上 昇量等の水理特性を検討した. また, 被覆材として 捨石や既存被覆ブロック(以下，Bブロックと呼ぶ) を用いた場合についても検討し，その結果を比較す ることで, エコリーフブロックの優位性を確認した. さらに，エコリーフブロック背後に小段を追加した 場合の波高伝達率等から小段背後伝達波の推定法に ついて検討した。

\section{3. エコリーフブロック形状}

エコリーフブロックは開ロスリット部における水 平乱流やブロック壁面内部の粗度抵抗等によってエ ネルギー損失を引き起こして消波を効果的におこな い，さらに内部空間を角型魚礁ブロックと同様にし て魚礁効果をも兼科備えている箱型被覆ブロックで ある.エコリーフブロック標準型の形状は, 長さ $4 \mathrm{~m}$ ×幅 $3 \mathrm{~m} \times$ 高さ $2 \mathrm{~m}$ であり, エコボックスとエコ消 波板から構成され，重量はおおよそ $300 \mathrm{kN}(30 \mathrm{tf})$ で ある.エコボックスの前後壁面および左右壁面の開 口部は開口率 $20 \%$ を有し，上面は開放されている. エコ消波板は $20 \%$ の開口率を持つ平板ブロックで あり，エコボックスの中に組み込まれる。なお，実 験に用いた形状は消波効果を考慮し消波板を $0.7 \mathrm{~m}$ 突出させた図-2 の標準型と $0.7 \mathrm{~m}$ 突出しないタイプ として消波効果が明瞭に現れるようにボックスのみ （消波板なし）のタイプを実験対象とした.

\section{4. 実験方法}

実験は, 長さ $22 \mathrm{~m}$, 幅 $0.8 \mathrm{~m}$, 深さ $2.0 \mathrm{~m}$ の片面 ガラス張り二次元造波水槽で, 不規則波を用いてお こなった. 模型縮尺は耐波安定性試験では $1 / 25$, 波 高伝達率等の水理特性試験では $1 / 30$ とした. 堤体模 型は $0.04 \mathrm{~N}(4 \mathrm{gf})$ 程度の砕石を用いてマウンドを形成 し，その上にブロック等を並べた（以下の数字は全

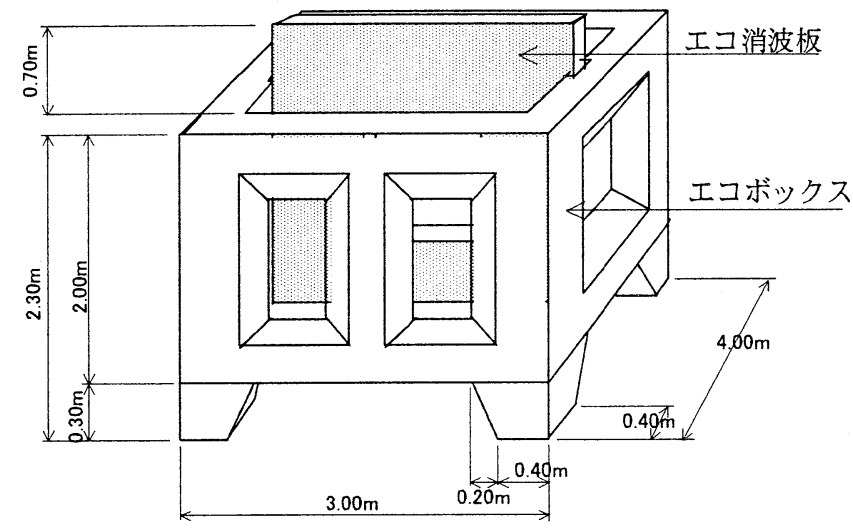

図-2 エコリーフブロック(標準型)形状

てフルード則による現地寸法).

耐波安定性試験では, 堤脚水深 $\mathrm{h}=12 \mathrm{~m}$ に, ブロ ック天端をエコボックスの天端として，ブロック天 端水深を $\mathrm{R}=2 \mathrm{~m}$ となるように天端長さ $\mathrm{B}=37.5 \mathrm{~m}$ の マウンドを形成した. そして, マウンド上にエコリ 一フブロックの敷設列数を 3 列から 8 列に変えて並 べ，表-1 の定義に従い，移動量を計測した．また， ビデオ撮影をおこない移動状況の把握をおこなった. 但し, 対象範囲は水平天端面である. 使用した実験 波の周期は $\mathrm{T}_{1 / 3}=10 \mathrm{sec}, 14 \mathrm{sec}$ であり, 入射波高 $(\mathrm{Hi})$ は $\mathrm{H}_{1 / 3}=4.0 \mathrm{~m} \sim 6.8 \mathrm{~m}$ の範囲で変化させた.

水理特性試験では, 堤脚水深 $\mathrm{h}=12 \mathrm{~m}$, マウンド天 端長さ（ブロック敷設長さ） $\mathrm{B}_{1}=24.5 \mathrm{~m}$ ，マウンド 高さ $\mathrm{D}=8 \mathrm{~m}$, ブロック天端水深 $\mathrm{R}=2 \mathrm{~m}$ の場合と堤脚 水深 $\mathrm{h}=14 \mathrm{~m}$, マウンド天端長さ (ブロック敷設長さ) $\mathrm{B}_{1}=24.5 \mathrm{~m}$, マウンド高さ $\mathrm{D}=8 \mathrm{~m}$, ブロック天端水 剁 $\mathrm{R}=4 \mathrm{~m}$ の場合の 2 設置条件でエコリーフブロッ ク（標準型），エコリーフブロック（消波板なし， $\mathrm{B}$ ブロック, 砕石の 4 種類の被覆形状に変更し, 波 高伝達率, 反射率, リーフ背後の水位上昇量を計測 し比較した. さらに, 人エリーフ背後にエコリーフ ブロックの敷設高さと同一の高さに小段天端長さ $\mathrm{B}_{2}=20.5 \mathrm{~m}$ のマウンドを設け小段通過後の伝達率等 を計測し，小段効果を確認した。使用した実験波の 周期は $\mathrm{T}_{1 / 3}=8 \mathrm{sec}, 10 \mathrm{sec}, 14 \mathrm{sec}$ であり，入射波高 (Hi) $\mathrm{H}_{1 / 3}=0.6 \mathrm{~m} \sim 8.1 \mathrm{~m}$ の範团で変化させた. 伝達 波, 反射波の計測は人エリーフの後方および前方に 設けた各 2 本の波高計による入反射分離推定法を用 いて計測した。データは造波開始後, 造波板已模型 の間を波が 3 往復する時間を経過してから, サンプ リング間隔 $0.031 \mathrm{sec〜0.063 \textrm {sec } て ゙ ~} 200$ 波分の波デー 夕を取得した. 水位上昇量はリーフ背後の 2 本の波 
高計の水位データの平均値とした.

表- 1 ブロックの移動の分類と定義

\begin{tabular}{|c|c|c|}
\hline ランク & 定 & 安定性 \\
\hline I & 全く移動しない. & \multirow{3}{*}{ 安定 } \\
\hline II & 基本長の $1 / 8(1.6 \mathrm{~cm})$ 末満で移動する. & \\
\hline III & 基本長の $1 / 4(3.3 \mathrm{~cm})$ 未満で移動する. & \\
\hline IV & 基本長の $1 / 4(3.3 \mathrm{~cm})$ 以上移動する. & 不安定 \\
\hline
\end{tabular}

\section{5. 耐波安定性}

図-3 はエコリーフブロック標準型を対象にした もので, 相対天端水深 $(\mathrm{R} / \mathrm{Hi})$ をパラメーターとして 相対ブロック長さ (ブロック敷設長さ $\mathrm{B}_{1} /$ 入射波波 長 L）と移動率の関係を示したものである.

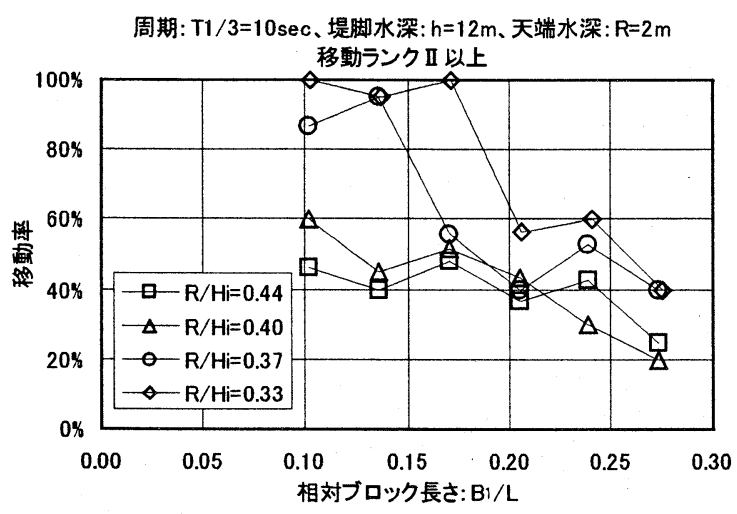

周期: $T 1 / 3=14 \mathrm{sec}$ 、堤脚水深: $h=12 m$ 、天端水深: $R=2 m$ 移動ランク吕以上

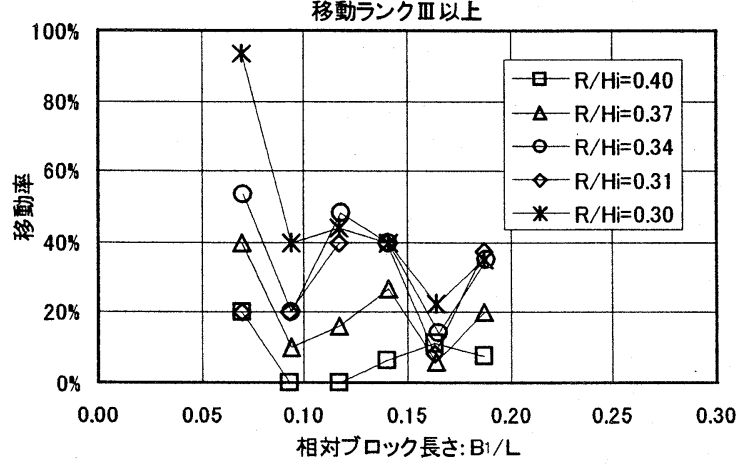

図-3＼cjkstart相対ブロック長さと移動率の関倸

上図の $\mathrm{T}_{1 / 3}=10 \mathrm{sec}$, 移動ランク II 以上の場合では $\mathrm{B}_{1} / \mathrm{L}=0.21$ に変化点があるものの, 各ラインとも穏 やかな直線を示し, 全体的に $\mathrm{B}_{1} / \mathrm{L}=0.25$ で $60 \%$ 以内, $\mathrm{B}_{1} / \mathrm{L}=0.275$ で $40 \%$ 以内と $\mathrm{B}_{1} / \mathrm{L}$ の大きくなるに従い 移動率が小さくなる傾向にある.これに比べて，下 図の $\mathrm{T}_{1 / 3}=14 \mathrm{sec}$, 移動ランク III以上では, $\mathrm{B}_{1} / \mathrm{L}=0.09$ 及び $\mathrm{B}_{1} / \mathrm{L}=0.16$ に移動率の変化点が生じている.リ 一フ斜面で砕波した波の波峰が気泡を伴いブロック 表面に落下するのがおおよそ $\mathrm{B}_{1} / \mathrm{L}=0.15$ 付近である ことを考えると， $\mathrm{T}_{1 / 3}=10 \mathrm{sec} ，$ 移動ランク II 以上の 場合では波峰の落下の影響が少ないようであるが,
$\mathrm{T}_{1 / 3}=14 \mathrm{sec}$, 移動ランク III 以上の場合には $\mathrm{B}_{1} / \mathrm{L}=0.16$ で移動率が最も下がっており波峰の落下の影響が考 えられ得る.この影響は，波峰の落下の際に発生す る流れに起因するものと考えられる.

エコリーフブロックの耐波安定性試験で，不安定 と定義される移動は, 今回の実験では生じなかった. 安定と定義される移動の中で発生した移動は, ブロ ックの抜け出しや転倒ではなく, 全て水平移動であ った.これは，エコリーフブロックが立体構造であ るため, 群体として機能するときには, 個々のブロ ックの抜け出しや転倒が生じ難いこと，エコリーフ ブロックにはエコ消波板が組み込められており抗力 が増大していること，およびスリット部や遊水部で のエネルギー逸散が大きいことが影響していると考 えられる.このため, ブロック間の隙間を詰める程 度の水平移動は発生するが, 全体的なブロック配置 は大きく変わらないものであった.

\section{6. 波浪制御特性}

\section{（1）伝達率［伝達波高 $(\mathrm{Ht}) /$ 入射波高 $(\mathrm{Hi})$ ]}

図-4 に被覆形状をパラメーターとする堤脚水深 別, 周期別の相対天端水深と伝達率の関係を示す.

伝達率の小さい被覆形状は，おおよそ，エコリー フブロック（標準型）＜砕石＜Bブロック<エコリ ーフブロック（消波板なし）である. エコリーフブ ロック（標準型）は最大で 1 割程度, 砕石よりも伝 達率が小さい。このように，エコボックス天端まで 砕石を盛り上げた場合の伝達率よりさらに伝達率が 小さいのは，エコボックス底盤上の砕波，エコリー フブロックおよびエコ消波板の開ロスリット部にお ける水平乱流，ブロック壁面の粗度抵抗等の消波効 果によるエネルギー損失が，エコボックス天端まで 砕石を盛り上げた場合の砕波によるエネルギー損失 よりもさらに大きい結果と思われる. エコリーフブ ロックのエネルギー消費の傾向として, 相対天端水 深が $\mathrm{R} / \mathrm{Hi}<1$ では，ブロック自体の消波に加えて， エコボックス底盤上での砕波の影響が強くでている が, 相対天端水深が $\mathrm{R} / \mathrm{Hi}>1$ になると, エコリーフ ブロック自体の消波が大きな影響を与えるようにな つており，低波浪に対しても高い伝達波の低減效果 があるものと思われる.

\section{(2) 反射率 [反射波高 $(\mathrm{Hr}) /$ 入射波高 (Hi)]}

図-5 に被覆形状をパラメーターとする堤脚水深 別, 周期別の相対天端水深と反射率の関係を示す.

どの形状も反射率は $0.1 \sim 0.3$ 程度と低く, 各被覆 形状の違いによる反射率の差は少ない，法面勾配が 1:3 と緩勾配であるためその影響と思わ的る。寒 用化においては，基礎マウンドの法面を緩勾配にさ えすれば，設置の目的に合わせて自由な選択が可能 と言える. 

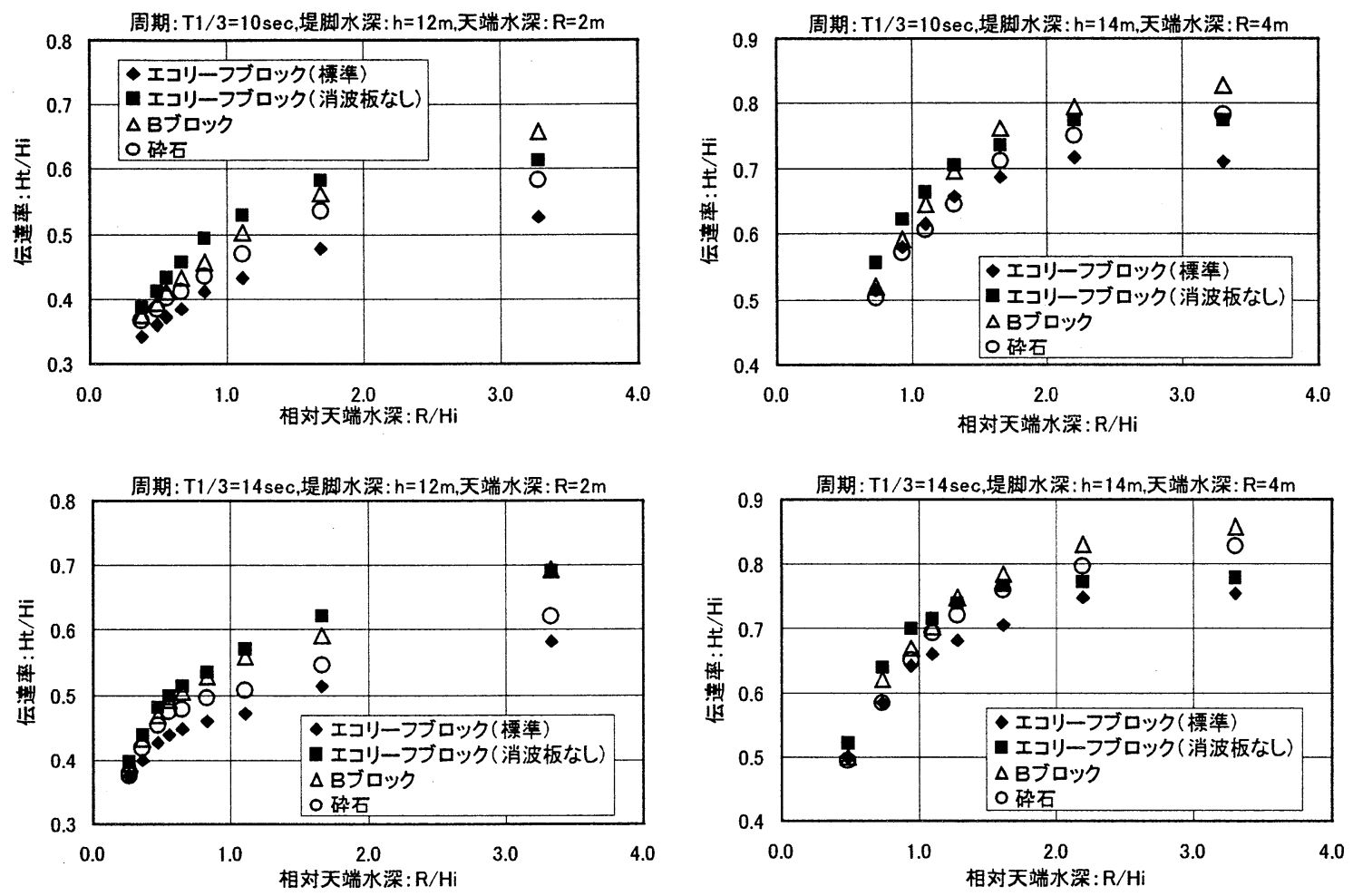

図-4＼cjkstart相対天端水深と伝達率の関係
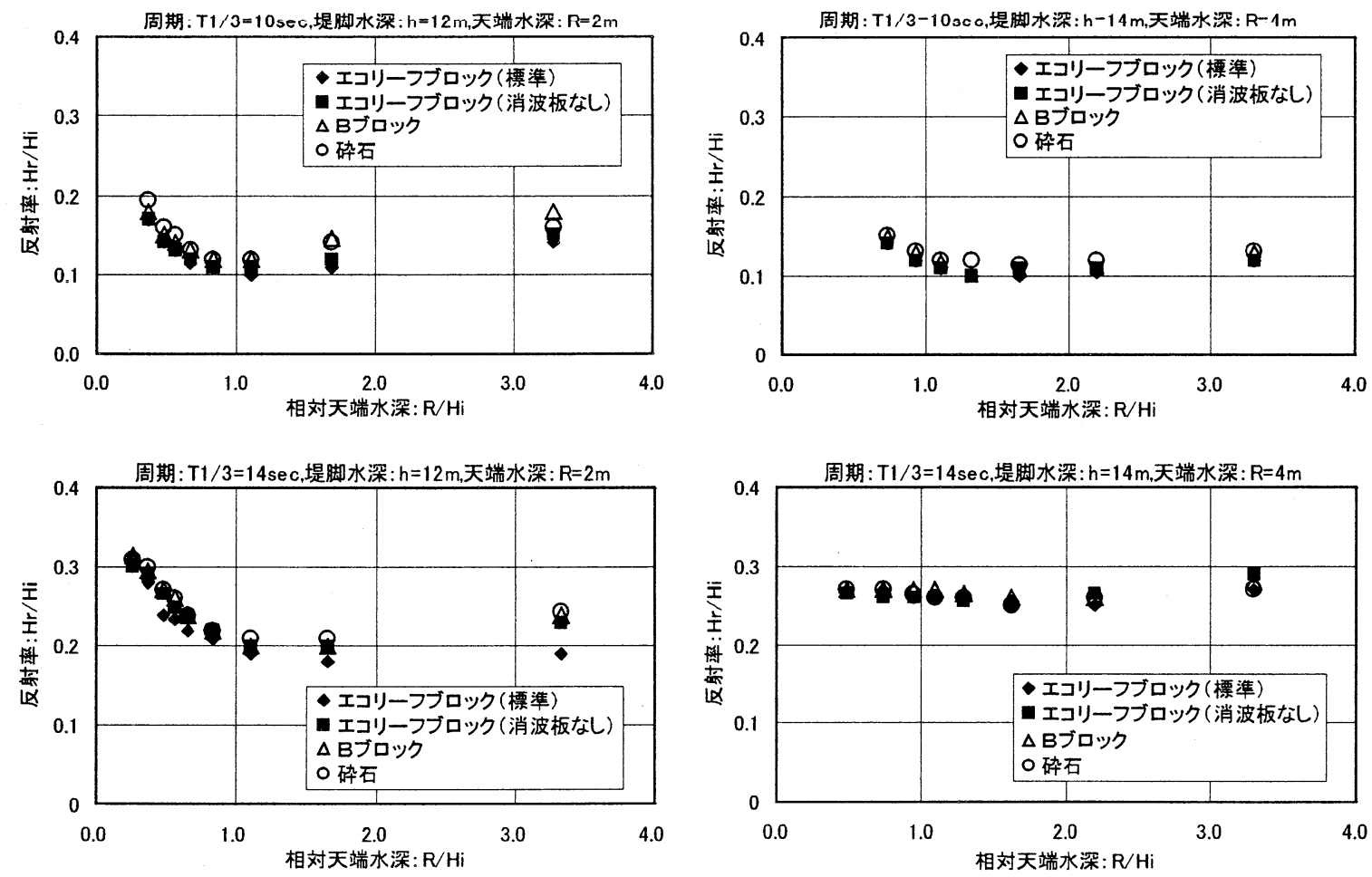

図-5＼cjkstart相対天端水深と反射率の関係

（3）平均水位上昇量 [水位上昇量 $(n)$ /入射波高 $(\mathrm{Hi})$ ] 被覆形状をパラメーターとする堤脚水深別, 周期 別の相対天端水深と相対水位上昇量の関係を図-6 に示す。

水位上昇量の小さい被覆形状はエコリーフブロッ ク（消波板なし）＜エコリーフブロック（標準型）
うBブロック<砕石の順である。一般に人エリーフ は伝達率や伝達波周期比が減少すると, 平均水位上 昇量が大きくなる傾向 2 2)あるが，エコリーフブロ ック（標準型）は，その傾向を示さず，伝達率が低 い割には水位上昇量は大きな值を示さなかった。こ れは, 前にも述べたとおり, 砕波によるエネルギー 

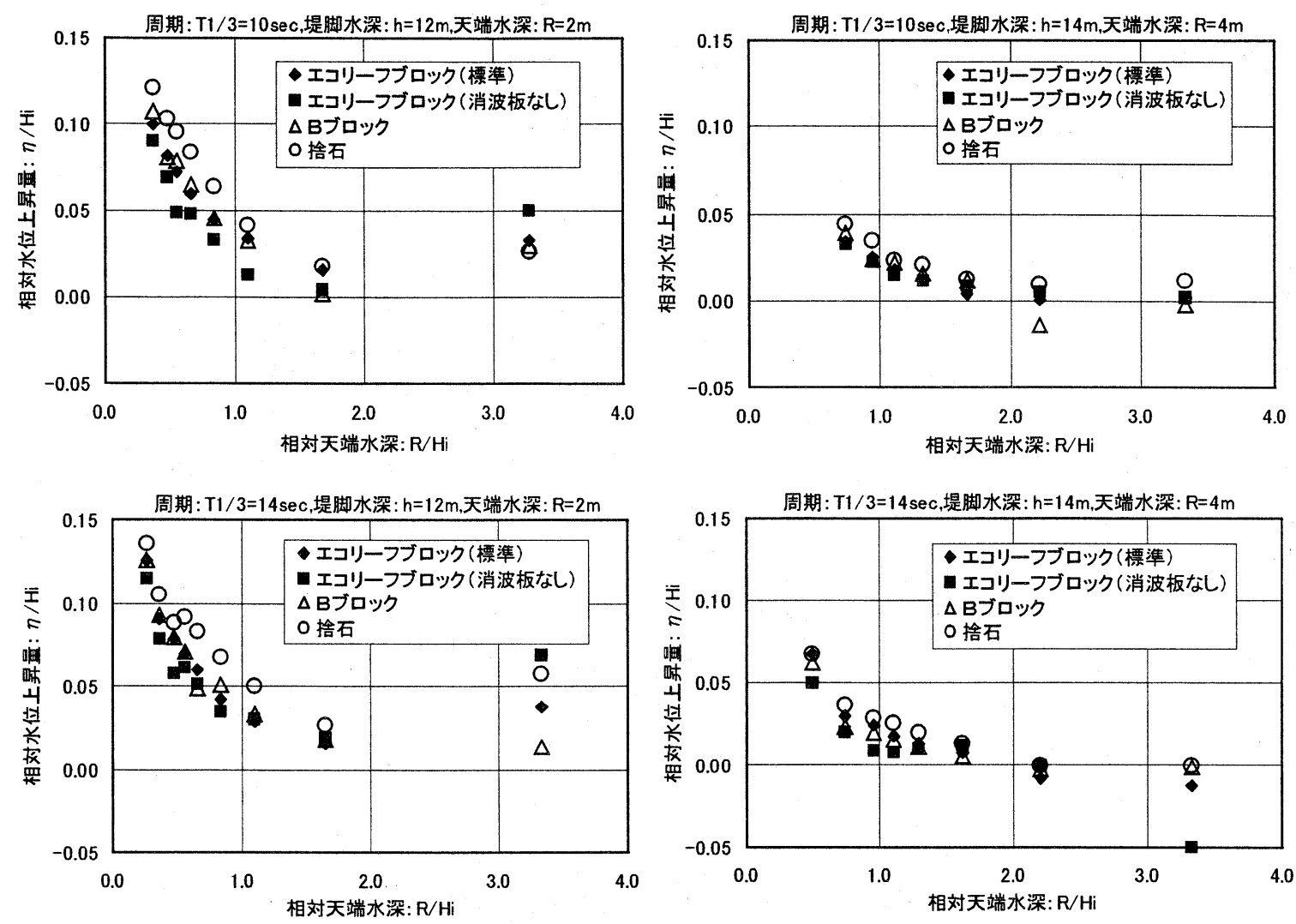

図-6 相対天端水深と水位上昇量の関係

減衰の実質水深がエコボックス底盤上水深であり, 砕波による水位上昇が砕石の場合より小さいことや エコリーフブロックは開口部を有しており, 背後で 上昇した水塊がエコリーフブロック遊水部を通過し て戻りやすいためと考えられる。

\section{7. 小段付き人エリーフの伝達波高 $(\mathrm{Ht})$ の試算}

図-1 の実用化モデルのような小段付き人エリー フを築造するためには, 背後利用目的を考慮した伝 達波高の推定が重要である.このために, 高山らの 研究成果 3$)$ を参考に実験結果からリーフ背後の伝達 波高の推定を試みた。

小段がない場合の波高伝達率を $\mathrm{Kt}_{1}=\mathrm{Ht}_{1} / \mathrm{Ho}^{\prime}$ ，小 段付きの場合の波高伝達率を $\mathrm{Kt}=\mathrm{Ht} / \mathrm{Ho}^{\prime}$ として, 小 段のみの伝達率を $\mathrm{Kt}_{2}=\mathrm{Ht} / \mathrm{Ht}_{1}$ とした。これより, 実験から得られた小段がない場合の伝達波高 $\left(\mathrm{Ht}_{1}\right)$ および小段を付けた時の伝達波高 $(\mathrm{Ht})$ の計測值から 小段がない場合の波高伝達率 $\left(\mathrm{Kt}_{1}\right)$ および小段のみ
の伝達率 $\left(\mathrm{Kt}_{2}\right)$ の関係式を最小二乗法により近似し, 小段付き人エリーフの伝達波高 $(\mathrm{Ht})$ を算出した.

小段がない場合の波高伝達率の関係式を(1)，(2) 式に示す. なお，堤脚水深が大水深域となることを 考慮し, 近似に用いるパラメーターに相対水深 (h/Ho')を加えた.

$$
\begin{aligned}
\mathrm{Kt}_{1}=-0.63 \frac{\mathrm{B}_{1}}{\mathrm{Lo}}+0.48 \frac{\mathrm{R}}{\mathrm{Ho}^{\prime}}-0.05 \frac{\mathrm{h}}{\mathrm{Ho}^{\prime}}+0.41 \\
0<\frac{\mathrm{R}}{\mathrm{Ho}^{\prime}}<1.0 \\
\mathrm{Kt}_{1}=-0.51 \frac{\mathrm{B}_{1}}{\mathrm{Lo}}+0.27 \frac{\mathrm{R}}{\mathrm{Ho}^{\prime}}-0.05 \frac{\mathrm{h}}{\mathrm{Ho}^{\prime}}+0.58 \\
1.0 \leqq \frac{\mathrm{R}}{\mathrm{Ho}^{\prime}}<2.5
\end{aligned}
$$

小段のみの伝達率の関係式を(3)式に示す.

$$
\begin{aligned}
\mathrm{Kt}_{2}=-0.28 \frac{\mathrm{B}_{2}}{\mathrm{Lo}}+0.026 \frac{\mathrm{r}}{\mathrm{Ht}_{1}}+0.90 & \\
& 0<\frac{\mathrm{r}}{\mathrm{Ht}_{1}}<4.0
\end{aligned}
$$

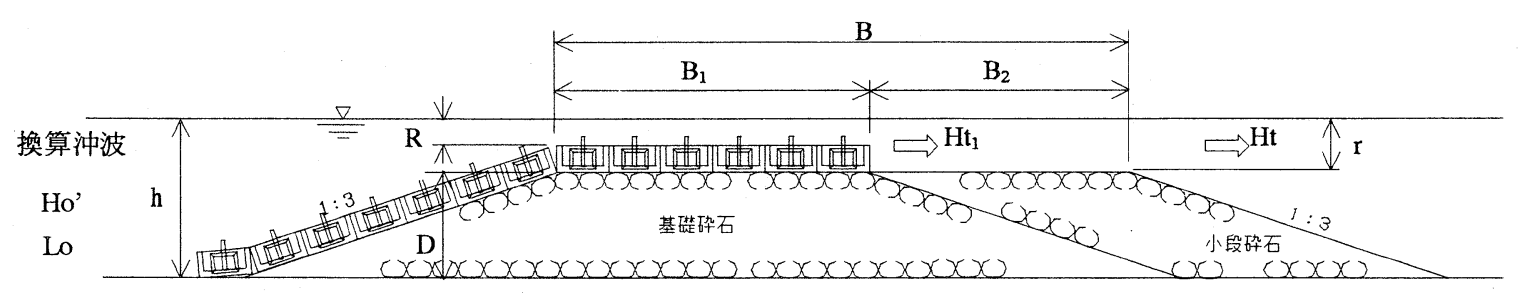

図-7 試算モデル 
図-8 は(1)，(2)式による $\mathrm{Kt}_{1}$ の計算値と実験値を比 較したものである. また, 図-9 は(3)式による Kt2 $の$ 計算值と実験值を比較したものである. 図-10 は(1), (2)式および(3)式を用いて, $\mathrm{Ht}=\mathrm{Kt}_{1} \cdot \mathrm{Kt}_{2} \cdot \mathrm{Ho}^{\prime}$ の関係 から伝達波高を計算で求め, 実験值と比較したもの である。図-8, 図-9, 図-10 とも多少のばらつきはあ るが，実験值は計算式によく一致した值を示してい る.これより(1)，(2)式および(3)式を用いて図-1に

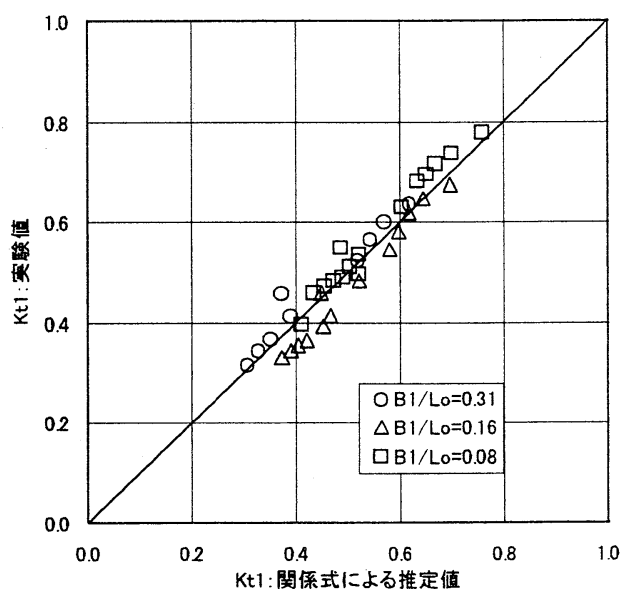

図-8 推定值と実験值の関係 $\left(\mathrm{Kt}_{1}\right)$

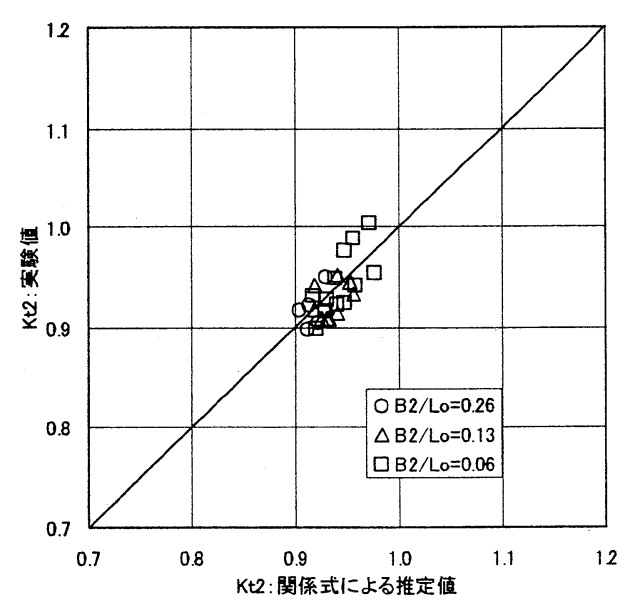

図-9 推定值と実験值の関係 $\left(\mathrm{Kt}_{2}\right)$

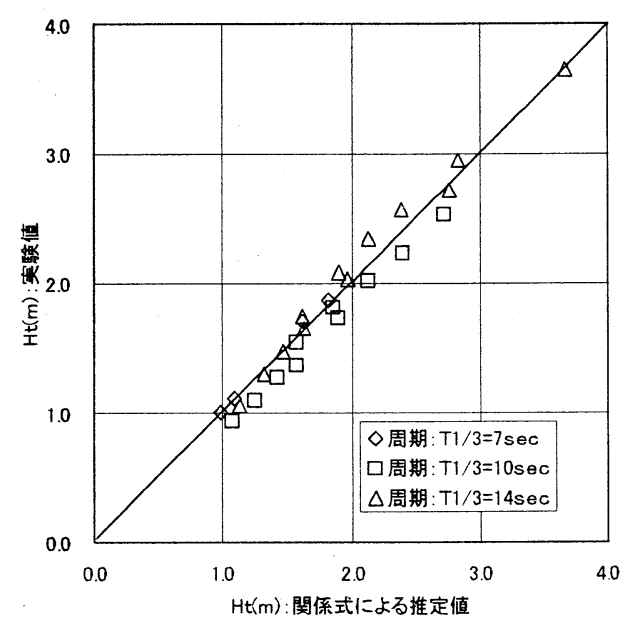

図-10 推定值と実験值の関係 $(\mathrm{Ht})$
示すような人エリーフの伝達波高を算定することが 可能であると考える.

\section{8. まとめ}

本研究によって，大水深域にエコリーフブロック を人エリーフの被覆材として用いた場合の耐波安 定性および水理特性について次の事項が確認でき た.

・エコリーフブロックの移動は，ほとんどがブロ ック間の隙間を詰める程度の水平移動であり，全 体的なブロック配置は大きくかわらない.

・エコリーフブロック（標準型）を有する人エリ

一フは，エコボックス自体および消波板の消波効 果によりブロック天端まで砕石を積み上げた場合 の波高伝達率より更に小さい伝達率をもつ.

・反射率は, 法面勾配が $1 ： 3$ 程度の緩勾配では 他の被覆形状と同程度の小さい值を示す.

・エコリーフブロック（標準型）の平均水位上昇 量注石材に比べると小さく, 水位低減効果がある. - 小段付き人エリーフの伝達波高の推定は関係式 (1)，(2)式および(3)式を用いることで可能である.

\section{9.あとがき}

以上により, 大水深域でのエコリーフブロックを 用いた人エリーフの水理特性等を明らかにするこ とができた。

なお，エコリーフブロックを人エリーフに適用す る場合の優位性の中で, 特に立体構造によるマウン ド捨石量の低減効果は, 近年の工費縮減の考え方に 沿った重要な効果であること, また, 魚礁効果の確 認をおこなうために実物大のエコリーフブロック を海中に設置し現在観察中であることを付記する。

謝辞 : 実験およびデー夕整理にあたっては, 当時北 海道東海大学大学院生の黄木恵治君, 同学生の沼田 泰裕および小野諭君に多大な協力を得た. ここに記 して謝意を表する.

\section{参考文献}

1)建設省河川局海岸課監修 : 人エリーフの設計の手 引き, 94p，全国海岸協会，1992.

2)たとえば，宇多高明・小俣篤・横山揚久：人工リ

一フの機能と設計法, 土木研究所資料, 第 2696 号, 79p, 1988.

3)高山知司・池田直太 : 広天端幅潜堤による波浪変 形と護岸越波流量の低減効果, 港研報告, 第 27 巻, 4 号, pp.63-92, 1988. 